Hrechaniuk R.

Administrative activity as characteristic of public administration

УДК 342.92

Roksolana Hrechaniuk,

Senior Research Fellow of the

National Prosecution Academy

of Ukraine

\title{
ADMINISTRATIVE ACTIVITY AS CHARACTERISTIC OF PUBLIC ADMINISTRATION
}

In the article the conducted development of theoretical aspects of determination of administrative activity is as part of state administration. The different scientific looks researched for formulation of concept of administrative activity, the basic constituents of this concept are certain in relation to state administration.

To understand the nature of the administrative activity, it is necessary to research different approaches to its understanding. Analysis of publications allows to consider administrative activity as: part of public administration; component of activities of law enforcement agencies; administrative management.

The main purpose of administrative activity as a characteristic of public administration is assurance of internal administration of performance of defined public tasks and strategic priorities of respective subject. Its effectiveness (through successful operational model, management decisions, administrative methods) can improve the quality of the statehood strategy in a specific area, sometimes by hiding its disadvantages. Administrative activity in public administration has certain features, which are related primarily to the fact that spheres of state influence are too diverse and, correspondingly, administrative processes in public administrative subjects differ depending on the need to perform certain tasks.

Keywords: administrative activity, management, legal procedures of administrative activity, state administration, organs of executive power, public regulation.

Bibl.: 15.

Formulation of the problem. Recently among the scientific community re-evaluation of numerous scientific postulates that were developed during the sioviet era were made. An issues of administrative activity is not an exception. In general, it should be noted that scientific research of this issue was not conducted actively and concerned mostly separate directions (functions) of activity of law enforcement agencies, as well as their management. The very same concept of administrative activity of law enforcement agencies is still not comprehensively developed.

It should be said that today material and procedural aspects of administrative activity of law enforcement agencies also cannot be considered sufficiently developed. Therefore it is necessary simultaneously with the development of general (material) aspects also to strengthen procedural ones, focusing on the fact that only through effective legal procedures of administrative activity the set goals can be achieved. Only through sustainable, stable legal procedures of administrative activity, clearly defined range of subjects of management activity, which are required within its competence to take appropriate measures, qualitatively new level of management process can be achieved through specified sequence of such actions.

The aim of the research. To understand the nature of the administrative activity, it is necessary to research different approaches to its understanding. Analysis of publications allows to consider administrative activity as:

- part of public administration;

- component of activities of law enforcement agencies;

- administrative management.

Presenting main material. Administrative activity as characteristic of public administration. We should immediately accept the fact, that the problem of determining the meaning and essence of public administration is one of the key issues not only in contemporary studies in the field of administrative theory (theory of management, administrative law), but also in legal science as such (by the way, even in foreign science of administrative law deviation from traditional reduction of public administration to exclusively administrative management exercised by the executive authorities is observed) [1, p. 18]. Public administration - is a very complex phenomenon and therefore is an object of study of various sciences. Philosophers study it as one of the types of public administration, specific expression of qualities of the latter. Sociologists are mainly interested in social and class nature and

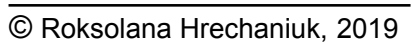


social function of public administration, their real and concrete reflection in social life. Economists mostly investigate the role of government in the economy, in the administration of social processes, as well as public administration as a specific type of labor [2, p. 26]. Thus, in G.V. Atamanchuk opinion, public administration - is organizing activity of the state, public regulation of different social relations through the activities of all branches of government - legislative, executive, judicial, their bodies, public officials [3, p. 11]. G. Petrov tried to prove that the most appropriate and scientifically justified interpretation of the notion of public administration is as follows: «Public administration - is an activity of executive and administrative bodies of state power, which is aimed to implement laws, manage and organize economic, cultural and defense construction» [4, p. 123]. Y. Kozlov analyzed four main features of public administration: 1) executive and administrative activity, the main focus of which is execution, i.e. implementation of laws, subordinate acts and other normative legal acts through the use of legal public powers; 2) it is the prerogative of special subjects, which are outlined by the notion of executive and administrative bodies of state power or bodies of public administration; 3 ) it is executive activity, which is carried out in the processe of everyday and direct management of economic, socio-cultural and political-administrative construction; 4 ) it is subordinate activity, which has a secondary character compared to legislative activity [5, p. 19]. Thus, public government is a complex phenomenon, which covers many different types of relationships, the main purpose and characteristic of which is the ability to influence public relations through legal, organizational and administrative measures with the purpose of their regulation and development.

Considering such our understanding the position of Y.M. Starilov, who administrative legal regulation presents by the following list of management relations seems relevant:

1) those, which arise within organization of public administration (organizational public law);

2) those, within which the functions and powers of bodies of executive authorities are implemented; are emerging between different links of the system of executive power and the bodies of public administration;

3 ) those associated with the activities of executive bodies of local government and which arise during the implementation of management process;

4) of internal organizational character, which arise in the process of functioning of subjects of representative, judicial power and prosecution;

5) those, associated with consideration of cases concerning protection of rights and freedoms of citizens from actions and decisions of public administration (their officials), which violate rights and freedoms of citizens;

6) those, that arise during the implementation of management activities delegated by the state to public organizations and other non-governmental organizations [6, p. 3-24].

Administrative activity in the sphere of public administration as one of the types of management activity also has all of its properties, adapted to the conditions of public administration. Elements of management activity inherent to administrative activity, have logical connection with management category, which determine the following characteristics: with what purpose administrative activity is carried out; what caused its implementation; on what object its actions were aimed; what kind of impact it makes [7]. At the same time it is possible to agree with S. Kyriy concerning that administrative activity in public administration is similar to operational management in the commercial sector with its inherent characteristics. The only difference is in the purpose of activity and ways of its achievement. Administrative activity as a kind of management activityis aimed at organizing various processes and their management [8, p. 59-67]. To continue aforementioned we should note opinion of A. M. Voloshchuk, who indicates that a significant number of scientists (especially those experts and lawyers, who are specializing in the field of administrative law), based on the provision on executive and administrative nature of public administration, expressed their support to the thesis concerning the deep connection of administrative activity with the process of functioning of executive branch. As a result, there is actual identification of public administration with management activity of executive bodies of state [9, p. 22]. As an example of similar definition of public administration the said author gives definition of L. Koval, who characterizes this phenomenon as an activity of specially formed bodies, public-service positions, which constitute the system of bodies of executive power [10, p. 22]. Understanding of public administration as administrative activity confirms the presence of different elements of administration. This allows us to consider administrative activity as characteristic of public administration.

In support of this, M. V. Razvadovska notes, that public administration in the narrow sense, i.e. as a specific kind of activity of state bodies, existed and continues to exist quite objectively. Insofar its basic meaning, the essence, namely organizational impact of the carriers of public authority (i.e. particular group of state authorities) on public relations and processes with the goal of their organization, coordination and direction with the help of 
Hrechaniuk R.

Administrative activity as characteristic of public administration

different normative and regulatory activities for implementation of laws and other legal acts of the state are not just preserving, but also gaining importance [11 p. 11].

As noted by L. Gordienko, administrative activity - is an activity of managers, which is carried out within a certain position and is the subject of research of administrative management. According to the division of administrative work she indicates, that official activity of the individual is the primary structural and functional element in the system of administrative work, i.e. she considers administrative activity from the perspective of analysis of the system «position -employee». The starting point of research of position as administrative category is determination of its basic systemic characteristics: structure, relationships, functions, organization [7]. Y. M. Kozlov, in particular, suggests characteristic features of management processes:

- management is always revealed in integrated and dynamic systems;

- management is the process of purposeful action on the system, as a result of which an ordered system, its development is achieved according to the common goals set before her;

- management influence is always realized in connections between two internal elements of any system: subsystem - subject of management and subsystem - object of management;

- links between subject and object of management are based on the circulation of information signals using direct communication and feedback;

- management influence assumes some hierarchy, according to which the subject forms aims and objectives of the movement of the entire system and subordinates to them the object, i.e. all other structural elements of the system;

- subordination within a controlled system is insured by management teams of the subject of management [12, p. 9-10].

A. Fayol, while exploring the issue of industrial administration, considered the notion of management as a form of administrative activity, i.e. in the light of the ability to manage personnel via prediction, organization, management, coordination and control [13]. We agree with S. Kyriy, who states that administrative, in the broad sense, - is the one which is associated in general with management activity as political, as well as administrative, in the narrow interpretation - the one, that is associated with bureaucratic method of management and implementation of political decisions. In the characteristic of management «influence» is a key element. For public administration general concept of governance is generic, and the transition to consideration of public administration suggests that the basis for the characteristics of the phenomenon remains the same. Only features inherent to this type of management are added, which distinguish it from administration in other areas of social life and are carried out by other entities [8, p. 59-67].

So, we should support the position of many scientists as to what public administration (in the administrative and legal context) should not be limited to the activities of bodies of the executive branch on implemention of regulatory requirements of laws and subordinate legislation for performance of public functions and achievement of stated objectives, as well as executive and administrative activity. Along with these characteristics intraorganizational or rather internal administrative component is not less important. At the same time management is the core element of administrative activity (in its narrow sense), which thus becomes necessary and important component (characteristic) of public administration [14, p. 32].

Administrative activity in the sphere of public administration as one of the types of management activity also has all of its properties, adapted to the conditions of public administration. Elements of management activity inherent to administrative activity have logical connection with administrative category, which determins such characteristics: with what purpose administrative activity is carried out; what has caused its implementation; at what object her actions are aimed; what type of influence it makes [7, p. 59-67].

Instead, it should be noted that administrative activity in public administration has certain features, which are related primarily to the fact that spheres of state influence are too diverse and, correspondingly, administrative processes in public administrative subjects differ depending on the need to perform certain tasks. For example, central executive bodies, which implement policy in the sphere of law, form their own intrastructural processes taking into account the nature of this type of policy, respectively specific objects of influence, priorities of activity and the need to interact primarily with specific state structures that are in the plane of formation and implementation of legal regulations. Concerning the activity of executive body for which legal policy is not a priority, and the priority is, for example, economics, administrative processes are aimed at internal organization and establishment of external relations in order this body will have a real opportunity to effectively influence economic processes. 
It is necessary to mention an interesting study of interrelation of administrative activity and executive power carried out by N. I. Zolotariova [15, p. 193-197]. According to the said author, the executive branch is part of state power, which belongs to the people of Ukraine. It is a separate branch of state power, systematic, coheren, willed, organizational, purposeful influence of specifically authorized bodies and officials, as well as other subjects of legal relations performing certain functions of administrative character on the base of delegated powers on actions, behavior of participants of legal regulation for the purpose of their regulation and protection for achieving the goals stated in the Constitution and laws of Ukraine and providing administrative services to citizens and other subjects of legal relations for realization of their rights and freedoms. Executive character of activity is common feature of executive power and administrative activity, insofar as both executive power and administrative activity are based on the performance of laws; sublegislation is the general principle of their functioning. Purposeful influence of the subject of management on the object of management, organizational character of such influence, as well as providing administrative services to citizens are their common features. Thus, administrative activity and executive power coincide in these aspects and may be considered as identical concepts. However, administrative activity of state authorities is a notion in some sense broader then the notion of executive power. First of all, by the subject of its exercise, it does not coincide with the executive power, which is carried out only by authorities of this branch of government and special institutions, which were delegated with authority to perform the functions of the bodies of the executive branch of government. At the same time administrative activity as management activity regulated by norms of administrative law, is performed not only by bodies of the executive branch of government. It is also inherent to bodies of other branches of government [15, p. 193-197].

Conclusions. Thus, summarizing the positions and theoretical works, it should be recognized that the main purpose of administrative activity as a characteristic of public administration is assurance of internal administration of performance of defined public tasks and strategic priorities of respective subject. Its effectiveness (through successful operational model, management decisions, administrative methods) can improve the quality of the statehood strategy in a specific area, sometimes by hiding its disadvantages.

\section{References}

1. Voloshchuk, A. (2004). Theoretical and legal aspects of public administration in terms of democratization of the political system: The thesis for obtaining scientific degree of candidate of legal sciences on specialty 12.00.07 «Theory of management; administrative law and process; finance law; information law»/Voloshchuk Anatolyi M.; National University of Internal Affairs of Ukraine. Kcharkiv.

2. Information, communication and telecommunications in Ukraine: economics, law, management (2001) / ed. S. O. Dovgy, B. I. Cholod. Kyiv Ukrtelecom.

3. General theory of management: Lectures / G. V. Atamanchuk, G. V. Belyaev, K. I. Varlamov, A. P. Ivanov; editorial board: A. A. Belyaev and others (1994). Moskow.

4. Fundamentals of Soviet State Law and Soviet construction. Lectures / V. A. Andersen, A. N. Arzamastsev, M. R Vaskovskiy, S. S. Golovanov and others.; Ed .: G. I. Petrov (1961). Leninhrad: Lenizdat.

5. Alekhin, A. P. (1996). Administrative Law of the Russian Federation. Moskow : Zertsalo.

6. Starilov, Y. N. (2000). Administrative law: the essence, problems of reform and new system. Jurisprudence, 5, 3-24.

7. Gordienko, L. Y. (2001). Management of public institutions : Textbook. Kcharkiv: HDEU Publishing House.

8. Kyriy, S. L. (2009). Administrative activities as structural and functional components of public administration. Public administration and local self-government: collection of scientific papers, 1, (pp. 59-67). Dnipropetrovsk : DRIDU NADU.

9. Voloshchuk, A. M. (2004). Theoretical and legal aspects of public administration in terms of democratization of the political system: The thesis for obtaining scientific degree of candidate of legal sciences on specialty 12.00.07 «Theory of management; administrative law and process; finance law; information law». Kcharkiv. National University of Internal Affairs of Ukraine.

10. Koval, L. V. (1996). Administrative Law. Kyiv: Venturi; Voloshchuk, A. M. (2004). Theoretical and legal aspects of public administration in terms of democratization of the political system: The thesis for obtaining scientific degree of candidate of legal sciences on specialty 12.00.07 «Theory of management; administrative law and process; finance law; information law»/Voloshchuk Anatolyi M. ; National University of Internal Affairs of Ukraine. Kcharkiv. 
Hrechaniuk R.

Administrative activity as characteristic of public administration

11. Razvadovska, M. V. (2005). Internal administrative activity of the Verkhovna Rada of Ukraine (organizational and legal framework): The thesis for obtaining scientific degree of candidate of legal sciences on specialty 12.00.07 «Theory of management; administrative law and process; finance law; information law». Kcharkiv : National University of Internal Affairs.

12. Public administration and administrative law / I. A. Azovkin, A. P. Alechin, Y. M. Kozlov, B. M. Lazarev and others.; ed. Y. M. Kozlov (1978). Moskow : Yurid.lit.

13. Sheldrake, J. (2001). Management Theory: from Taylorism to Japanization / J. Sheldrake; translated from English. ed. V. A. Spivak. SPb. : Peter.

14. Puzyrnyi, V. F. (2014). Understanding and meaning of administrative activity in public administration. Scientific Bulletin of Kherson State University. Series «Jurisprudence», 6-1 (3), 30-33.

15. Zolotariova, N. I. (2011). Interrelation of executive power and administrative activity. Bulletin of NTUU «KPI». Politology. Sociology. Law : collection of scientific papers, 1 (9), 193-197.

Стаття надійшла до редакції 16.06.2019. 